\title{
Pengaruh Penggunaan Media Zoom Meeting dalam Pembelajaran Online terhadap Hasil Belajar
}

\section{Maya Tahta Alfina ${ }^{1 *}$, Ratnawati Susanto ${ }^{2}$}

1,2 Universitas Esa Unggul, Jakarta, Indonesia

\section{A R T I C L E I N F O}

Article history:

Received September 26, 2021

Revised September 28, 2021

Accepted October 30, 2021

Available online December 25, 2021

Kata Kunci:

Zoom Meeting, Pembelajaran Online,

Hasil Belajar

Keywords:

Zoom Meeting, Online Learning, Learning Outcomes

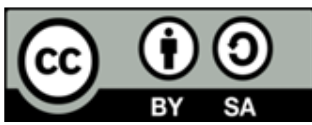

This is an open access article under the CC BY-SA license.

Copyright (c) 2021 by Author. Published by Universitas Pendidikan Ganesha.

\begin{abstract}
A B S T R A K
Kurangnya proses tatap muka antara guru dan siswa selama proses pembelajaran daring berdampak pada rendahnya hasil belajar siswa, sehingga untuk mengatasi hal tersebut guru berupaya untuk melaksanakan proses tatap muka virtual dengan menggunakan aplikas zoom meeting. Tujuan penelitian ini yakni untuk mengetahui pengaruh penggunaan media zoom meeting dalam pembelajaran online terhadap hasil belajar siswa kelas IV SD. Penelitian ini merupakan penelitian kuantitatif dengan menggunakan media survey. Populasi dalam penelitian ini ialah siswa kelas IVA yang berjumlah 32 siswa. Pengumpulan data dalam penelitian dilakukan dengan teknik observasi, wawancara, serta penyebaran angket. Instrumen angket yang digunakan yakni berupa kuesioner intensitas penggunaan zoom meeting serta kuisioner hasil belajar siswa. Data hasil penelitian kemudian dianalisis dengan menggunakan uji parsial (uji t) untuk menentukan hipotesis. Hasil hipotesis yang diperoleh berdasarkan pengujian parsial (uju t) yaitu 3,088 > t_(tabel ) 2,042 dengan signifikan $0,000<0,005$. Hasil tersebut menunjukkan bahwa $\mathrm{H} 1$ diterima dan Ho ditolak. Dapat disimpulkan bahwa terdapat pengaruh positif dan signifikan media zoom meeting terhadap hasil belajar siswa kelas IVA SD.
\end{abstract}

\section{A BS TRACT}

The lack of a face-to-face process between teachers and students during the online learning process has an impact on the low learning outcomes of students, so to overcome this the teacher seeks to carry out a virtual face-to-face process using the zoom meeting application. So the purpose of this study is to determine the effect of using zoom meeting media in online learning on the learning outcomes of fourth grade elementary school students. This research is quantitative research using survey media. The population in this study were students of class IVA, totaling 32 students. Data collection in the study was carried out by means of observation, interviews, and questionnaires. The questionnaire instrument used is a questionnaire on the intensity of using zoom meetings and a questionnaire on student learning outcomes. The research data were then analyzed using a partial test ( $t$ test) to determine the hypothesis. The results of the hypothesis obtained based on partial testing (uju $t$ ) are $3.088>t_{\text {_t }}$ table) 2.042 with a significance of $0.000<0.005$. These results indicate that $\mathrm{H} 1$ is accepted and $\bar{H}_{0}$ is rejected. So that it can be concluded that there is a positive and significant influence between the media zoom meeting on the learning outcomes of grade IVA elementary school students.

\section{PENDAHULUAN}

Pendidikan merupakan sarana yang dapat digunakan oleh individu untuk mengembangkan diri guna meningkatkan kemampuan untuk kehidupannya (Kadi \& Awwaliyah, 2017; Koswara, 2018). Melalui pendidikan, seseorang akan dapat meningkatkan taraf hidupnya, sehingga dapat diterima dengan baik oleh masyrakat. Pada umumnya, pelaksanaan pendidikan dilakukan melalui proses tatap muka langsung antara guru dan peserta didik di dalam kelas dengan memanfaatkan berbagai sarana dan prasarana yang ada (Anggianita et al., 2020; Tanuwijaya \& Tambunan, 2021; Wiryanto, 2020). Hanya saja dengan adanya 
pandemi covid-19 yang melanda berbagai negara di dunia termasuk Indonesia, pelaksaan pendidikan tidak dapat berjalan dengan normal (Suhendro, 2020). Selain memberikan pengaruh pada pelaksanaan pendidikan di Indonesia, pandemic covid-19 juga telah memberikan dampak pada seluruh tatanan kehidupan masyarakat. Untuk menekan penyebaran virus covid-19 di lingkungan pendidikan, pemerintah mengeluarkan kebijakan pembatasan pelaksanaan pembelajaran melalui proses pembelajaran jarak jauh (Yunitasari \& Hanifah, 2020).

Pembelajaran jarak jauh merupakan kegiatan pembelajaran yang melibatkan guru dan siswa belajar tidak pada tempat yang sama (M. Dewi, 2020; Jaelani et al., 2020). Pelaksanaan pembelajaran jarak jauh di masa pandemi seperti saat ini dilaksanakan melalui model pembelajaran daring (dalam jaringan) (Ali et al., 2020; Salsabila et al., 2020; Satrianingrum \& Prasetyo, 2020). Pembelajaran daring menjadi salah satu bentuk terobosan baru dalam bidang pendidikan, kususnya pada bidang pemanfaatan teknologi pendidikan (Mu'ayyadah \& Fatmawati, 2021). Melalui proses pembelajaran daring, guru dan siswa tidak perlu harus bertemu secara tatap muka langsung, melainkan hanya memanfaatkan media elektronik yang tersedia (Rigianti, 2020). Pembelajaran daring dilaksanakan dengan memanfaatkan berbagai aplikasi virtual, Konsep dari proses pembelajaran daring pada dasarnya hampir sama dengan proses pembelajaran konvensional hanya saja dituangkan dalam format digital melalui jaringan internet (Imania \& Bariah, 2019; Syarifudin, 2020).

Pembelajaran daring menjadi salah satu solusi terbaik yang bisa digunakan saat proses pembelajaran jarak jauh di masa pandemi (Yunitasari \& Hanifah, 2020). Hal ini dikarenakan pembelajaran daring memungkinkan siswa untuk mengikuti kegiatan pembelajaran di mana saja dan kapan saja, sehingga dalam proses pelaksanaannya siswa dapat mengondisikan diri senyaman mungkin untuk belajar tanpa aturan yang formal. Melalui pelaksanaan pembelajaran daring, peserta didik juga dapat menghemat waktu serta tenaga dalam melaksanakan proses pembelajaran, sehingga peserta didik memiliki waktu lebih untuk melakukan berbagai macam kegiatan di luar kegiatan akademik, misalnya mengikuti lomba, mengikuti les tari, atau pengembangan bakat dan minat lainnya (Nugraha et al., 2020; Sobron et al., 2019; Wahyono et al., 2020).

Hanya saja pada pelaksanaannya dil apangan terdapat berbagai kendala yang dirasakan oleh guru dan siswa selama proses pembelajaran daring (Abidin et al., 2020; Dewi \& Sadjiarto, 2021). Kendala yang paling banyak dirasakan yakni kendala yang berkaitan dengan teknis pelaksanaan pembelajaran daring. Misalnya, guru yang belum mampu menyampaikan materi dengan baik kepada siswa (Arini \& Wiguna, 2021; Rigianti, 2020). Dalam pembelajaran daring, proses tatap muka antara guru dan siswa sangat jarang terjadi. Guru cenderung hanya memberikan tugas kepada siswa, tanpa memberikan pemaparan materi terlebih dahulu (Pujowati, 2021; Sartika, 2021; Zunanni \& Zahara, 2021). Selain itu, tidak jarang terdapat guru yang tidak mengenal wajah siswanya sama sekali karena tidak pernah bertemu atau bertatap muka. Proses pembelajaran yang demikian akan menimbulkan kesan membosankan bagi siswa, sehingga kemudian berdampak pada penurunan motivasi dan hasil belajar siswa.

Untuk mengatasi hal tersebut, maka dibutuhkan suatu media yang dapat mempertemukan guru dan siswa secara virtual. Salah satu media yang dapat digunakan yakni platform zoom meeting. Zoom meeting ialah sebuah media pembelajaran yang menggunakan video (Haqien \& Rahman, 2020). Media ini bisa dilakukan dengan siapa pun lewat video (Monica \& Fitriawati, 2020). Oleh karena itu, media ini cocok diguanakan sebagai media pembelajaran pada masa pandemi agar siswa dapat memahami apa yang dijelaskan oleh guru melalui media zoom meeting tersebut. Penggunaan media zoom meeting ini sudah umum digunakan (Permatasari, 2021). Hal ini merupaka salah satu cara untuk memutuskan rantai penyebaran virus Covid-19. Proses penggunaan media ini untuk tercapainya tujuan pembelajaran merupakan proses pembelajaran yang cocok diterapkan sesuai dengan situasi seperti ini. Media pembelajaran ini sebuah alternatif pembelajaran yang berdasarkan elektronik dan memberikan manfaat banyak sekali terutama dalam proses pendidikan yang dilakukan dengan cara jarak jauh (Far, 2021).

Beberapa penelitian yang telah dilakukan sebelumnya menyatakan bahwa penggunaan platform zoom meeting secara signifikan mampu meningkatkan hasil belajar mahasiswa (Langi, 2021). Penelitian lainnya juga menyebutkan bahwa pembelajaran daring via zoom berpengaruh terhadap hasil belajar siswa pada mata pelajaran IPS (Azizah \& Amalia, 2021). Penelitian selanjutnya juga menyebutkan bahwa terdapat pengaruh dalam penggunaan platform zoom terhadap motivasi dan hasi belajar siswa (Vegatama \& Amiruddin, 2021). Berdasarkan beberapa hasil penelitian tersebut dapat dikatakan bahwa penggunaan platform zoom meeting secara signifikan mampu meningkatkan hasil belajar serta motivasi belajar siswa. Hanya saja pada penelitian sebelumnya belum terdapat kajian mengenai pengaruh penggunaan media zoom meeting dalam pembelajaran online terhadap hasil belajar siswa, kususnya siswa kelas IV. Oleh karena itu, penelitian ini difokuskan pada kajian tersebut dengan tujuan untuk mengetahui pengaruh penggunaan media zoom meeting dalam pembelajaran online terhadap hasil belajar siswa kelas IV SDN Kembangan Utara 012 Petang. 


\section{METODE}

Penelitian ini merupakan jenis penelitian kuantitatif dengan menggunakan metode survey. Penelitian ini dilakukan sebagai upaya untuk mencari pengaruh penggunaan media zoom meeting dalam pembelajaran online terhadap hasil belajar siswa. Terdapat 2 variabel dalam penelitian ini, ialah variabel penggunaan media zoom meeting $(x)$ dan variabel Hasil Belajar $(y)$. Jumlah populasi dalam penelitian ini yakni sebanyak 32 orang siswa kelas IV. Penarikan sampel penelitian dilakukan dengan menggunakan teknik sampel total, yakni seluruh populasi dijadikan sebagai sampel penelitian. Pengumpulan data dalam penelitian dilakukan dengan menggunakan metode wawancara, dokumentasi, dan penyebaran angket. Instrumen penelitian yang digunakan berapa kuesioner menggunakan google form yang diisi oleh responden dengan memilih satu opsi dari beberapa opsi yang tersedia. Dari penelitian ini ada 2 instrumen yang digunakan, ialah penggunaan media zoom meeting $(x)$ dan hasil belajar $(y)$. Instrumen angket untuk mengukur variabel $\mathrm{X}$ mengenai penggunaan media zoom meeting disusun dengan menggunakan skala Likert dengan 4 opsi, yaitu: Selalu (SL), Sering (SR), kadang-Kadang (KD), dan Tidak Pernah (TP). Setelah mendapatkan data dari responden, dilakukan uji validitas dan uji reliabilitas untuk mengetahui kevalidan dan reliabel instrumen yang digunakan. Selanjutnya, angket uji coba yang telah dilakukan uji validitas dan reliabilitas disebar kembali kepada responden yang menjadi sampel penelitian. Setelah didapatkan data kembali dari responden, dilakukan uji regresi linear sederhana, uji normalitas, uji korelas, uji determinasi, dan uji parsial (uji t).

\section{HASIL DAN PEMBAHASAN}

Hasil

Penelitian ini untuk memperoleh gambaran dari pengaruh penggunaan media zoom meeting dalam pembelajaran online terhadap hasil belajar siswa kelas IVA di SDN Kembangan Utara 012 Petang. Sebelum melaksanakan penelitian, angket yang diberikan kepada sampel diuji terlebih dahulu oleh ahli, selanjutnya angket diuji coba validitasnya. Hasil uji coba di kelas IVB pada uji validitas angket media zoom meeting dalam pembelajaran online diperoleh 26 butir pernyataan yang valid dari total 30 butir pernyataan 4 pernyataan yang tidak valid tidak digunakan dan angket disebar kembali di kelas IVA, sehingga hasil uji validitas angket diperoleh 26 pernyataan valid dari 26 pernyataan angket. Pada uji reliabilitas diperoleh nilai $\mathrm{r}_{11}$ pada angket penggunaan media zoom meeting dalam pembelajaran online sebesar 0,877 dan dinyatakan reliable dengan keterangan interpretasi tinggi.

Selanjutnya, dilakukan pengumpulan data pernyataan angket media zoom meeting dari 30 pernyataan dengan 4 pilihan jawaban yang diberikan adalah 1,2,3 dan 4. Data yang didapat kemudian dianalisis dengan SPSS For Windows realease 22. Hasil survey pada angket tersebut menunjukkan bahwa sebanyak $88.6 \%$ siswa menjawab selalu karena penggunaan media zoom meeting yang digunakan guru dapat merespon perilaku belajar positif siswa dalam pembelajaran online. Siswa dapat bertanya kepada guru dan bersemangat belajar pada saat pembelajaran online. Sebanyak $85.1 \%$ siswa menjawab selalu karena media zoom meeting yang digunakan dapat memudahkan siswa dalam memahami materi yang diajarkan oleh guru, sehingga dapat menunjukkan pemahamannya apabila diminta guru menjelaskan dengan contoh dan siswa dapat mengerjakan soal latihan dengan baik setelah mendapatkan penjelasan materi dari guru.

Langkah selanjutnya ialah melakukan uji regresi linear yang terdiri dari uji regresi linear sederhana dan uji normalitas. Diketahui bahwa nilai pada linear sederhana X dan Y ialah konstanta $(\alpha)$ 59,334 dan nilai (b) atau koefisien regresi sebesar 0,213, sehingga persamaan regresi dapat ditulis $Y=$ $59,334+0,213$. Uji normalitas dengan menggunakan model regresi serta menggunakan rumus liliefors dengan taraf signifikan 0,05. Perhitungan uji normalitas diperoleh nilai signifikan sebesar 0,200>0,005 data berdistribusi normal. Berdasarkan hasil uji kolerasi (r) diperoleh koefesien 0,491 dengan nilai signifikan $0,004<0,0005$, sehingga berdasarkan data tersebut variabel penggunaan media zoom meeting dalam pembelajaran online terhadap hasil belajar berpengaruh positif dan siginifikan. Semakin baik penggunaan media zoom meeting yang dikuasai oleh guru akan menghasilkan hasil belajar yang baik.

Selanjutnya, hasil uji determinasi $\mathrm{r}^{2}$ pada kolom Rsquare membuktikan variabel penggunaan media zoom meeting dalam pembelajaran online terhadap variabel hasil belajar memperoleh sebesar 0,241 . Hal ini berarti $24,1 \%$ variasi terikat yaitu hasil belajar siswa. Dengan sebesar $24,1 \%$ dapat dijelaskan bahwa hasil belajar siswa dapat dibentuk melalui media zoom meeting dan sisanya sebesar $75,9 \%$ dibentuk melalui factor lain yang tidak diteliti dalam penelitian ini. Hasil ini menunjukan $H_{0}$ ditolak dan $H_{1}$ diterima yang artinya terdapat pengaruh positif dan signifikan terhadap media zoom meeting dan hasil belajar siswa 


\section{Pembahasan}

Berdasarkan hasil analisis penelitian didapatkan hasil bahwa terdapat pengaruh positif dan signifikan terhadap media zoom meeting dan hasil belajar siswa. Hasil yang diperoleh pada penelitian ini tidak terlepas dari karakteristik media zoom meeting yang mampu memenuhi kebutuhan belajar siswa di masa pandemi covid-19. Zoom meeting merupakan aplikasi yang memungkinkan seseorang dapat melakukan konferensi jarak jauh dengan menggabungkan konferensi video, pertemuan online, obrolan, hingga kolaborasi seluler (Monica \& Fitriawati, 2020; Wilson, 2020). Zoom meeting dapat diakses melalui website, baik untuk OS Mac, Windows, Linux, iOS, maupun Android (Layla, 2020). Aplikasi zoom memungkinkan penggunanya untuk bertatap muka secara virtual bersama lebih dari 100 orang peserta. Selain itu, aplikasi zoom juga menawarkan kualitas gambar dan suara yang jernih, sehingga meningkatkan kenyamanan pengguna (Langi, 2021). Dalam aplikasi zoom, pengguna juga dapat berbagi layar secara bersama-sama dan ikut menulis catatan penting dari hasil rapat untuk pertemuan yang lebih interaktif dengan kolaborasi bawaan (Tamin, 2021).

Keunggulan lain yang dimiliki oleh aplikasi zoom yakni memungkinkan pengguna untuk mengaktifkan penjadwalan terhadap video conference yang akan dilakukan saat meeting (Komalasari, 2020). Peserta juga dapat memulai video conference atau rapat melalui akun Outlook, Gmail, atau iCal yang dimiliki (Haqien \& Rahman, 2020; Vegatama \& Amiruddin, 2021). Dari segi keamanan aplikasi zoom menambahkan adanya fitur end-to-end encryption yang dapat digunakan pada saat rapat agar keamanan para penggunanya tetap terjaga (Azizah \& Amalia, 2021). Keamanan tambahan tersebut dapat diperoleh dari kata sandi yang hanya diketahui oleh pengguna (Farfar, 2021). Peserta rapat juga dapat merekam rapat yang dilakukan melalui aplikasi zoom kemudian menyimpan hasil rekaman di perangkat masingmasing atau pada akun cloud (Layla, 2020). Berbagai keunggulan yang dimiliki oleh aplikasi zoom sangatlah sesuai dengan kebutuhan siswa dalam pelaksanaan pembelajaran daring karena pada pembelajaran daring siswa dituntut untuk belajar dengan memanfaatkan berbagai teknologi digital (Baihaqi, 2021). Selain itu, aplikasi zoom juga mampu mengatasi permasalahan guru dalam proses pembelajaran daring. Sebelumnya, guru masih memiliki keterbatasan dalam melaksanakan proses tatap muka dengan siswa. Dengan adanya aplikasi zoom itu, guru bias bertatap muka dengan siswa secara virtual sesuai dengan jadwal yang telah disepatakti bersama.

Adanya kegiatan tatap muka antara guru dan siswa dalam pembelajaran daring tentunya memberikan pengaruh positif terhadap hasil belajar siswa. Dengan adanya tatap muka virtual guru dapat memberikan pemaparan materi secara lebih jelas dan terperinci kepada siswa. Selain itu, guru juga dapat memotivasi siswa agar lebih semangat belajar. Secara tidak langsung hal ini akan berdampak pada peningkatan hasil belajar siswa. Hasil yang diperoleh pada penelitian ini sejalan dengan beberapa hasil penelitian terdahulu yang mengungkapkan bahwa penggunaan platform zoom meeting secara signifikan mampu meningkatkan hasil belajar mahasiswa (Langi, 2021). Penelitian lainnya juga menyebutkan bahwa pembelajaran daring via zoom berpengaruh terhadap hasil belajar siswa pada mata pelajaran IPS (Azizah \& Amalia, 2021). Penelitian selanjutnya juga menyebutkan bahwa terdapat pengaruh dalam penggunaan platform zoom terhadap motivasi dan hasi belajar siswa (Vegatama \& Amiruddin, 2021). Berdasarkan hasil penelitian ini, yang didukung oleh hasil penelitian terdahulu maka dapat dikatakan bahwa platform zoom meeting sangat layak digunakan dalam pembelajaran daring kerena dapat meningkatkan hasil belajar, motivasi belajar, serta kemampuan berpikir kritis siswa.

\section{SIMPULAN}

Berdasarkan hasil analisis data dan pembehahasan dapat disimpulkan bahwa terdapat pengaruh positif dan signifikan penggunaan media zoom meeting dalam pembelajaran online terhadap hasil belajar. Oleh karena itu, direkomendasikan bahwa media zoom meeting digunakan sebagai salah satu solusi pelaksanaan pembelajaran daring pada masa pandemi covid-19,

\section{DAFTAR RUJUKAN}

Abidin, Z., Hudaya, A., \& Anjani, D. (2020). Efektivitas Pembelajaran Jarak Jauh pada Masa Pandemi Covid19. Research and Development Journal of Education, 1(1), 131. https://doi.org/10.30998/rdje.v1i1.7659.

Ali, M., Prawening, C., \& Samiaji, M. H. (2020). Inovasi Model Pembelajaran Jarak Jauh Program Kesetaraan Paket C di Masa Pandemi Covid-19. JIV-Jurnal Ilmiah Visi, 15(2), 107-116. https://doi.org/10.21009/JIV.1502.2.

Anggianita, S., Yusnira, Y., \& Rizal, M. S. (2020). Persepsi Guru terhadap Pembelajaran Daring di Sekolah Dasar Negeri 013 Kumantan. Journal of Education Research, 1(2), 177-182. 
https://doi.org/10.37985/joe.v1i2.18.

Arini, N. M., \& Wiguna, I. B. A. A. (2021). Hambatan dan Kendala dalam Pelaksanaan Pembelajaran Daring Pasca Covid-19. Cetta: Jurnal Ilmu Pendidikan, 4(3), 343-357. https://doi.org/10.37329/cetta.v4i3.1356.

Azizah, N., \& Amalia, A. N. (2021). Pengaruh Pembelajaran Daring via Zoom Meeting terhadap Hasil Belajar Siswa Kelas VIII Mata Pelajaran Ilmu Pengetahuan Sosial. Almufi Jurnal Pendidikan (AJP), 1(2), 04. https://doi.org/10.37081/ed.v9i3.2822.

Baihaqi, M. I. (2021). Assesmen Pelaksanaan Belajar dari Rumah Selama Darurat Covid - 19. JKTP: Jurnal Kajian Teknologi Pendidikan, 4(4), 408-416. https://doi.org/10.17977/um038v4i42021p408.

Dewi, M. (2020). Analisis Kerja Sama Guru dengan Orang Tua dalam Pembelajaran Online di Era Covid 19 Di Mi Azizan Palembang. Jemari (Jurnal Edukasi Madrasah Ibtidaiyah), 2(2), 54-64. https://doi.org/10.30599/jemari.v2i2.661.

Dewi, T. A. P., \& Sadjiarto, A. (2021). Pelaksanaan Pembelajaran Daring pada Masa Pandemi Covid-19. Jurnal Basicedu, 5(4), 1909-1917. https://doi.org/10.31004/basicedu.v5i4.1094.

Far, G. (2021). Efektifitas Penggunaan Aplikasi Zoom Meeting dalam Pembelajaran di Masa Pandemi Covid-19. Jurnal Pendidikan Dan Sejarah, 17(1). https://doi.org/10.21831/istoria.v17i1.37421.

Farfar, G. (2021). Efektifitas Penggunaan Aplikasi Zoom Meeting dalam Pembelajaran. ISTORIA: Jurnal Pendidikan Dan Sejarah, 17(1), 1-5. https://doi.org/10.21831/istoria.v17i1.37421.

Haqien, D., \& Rahman, A. A. (2020). Pemanfaatan Zoom Meeting untuk Proses Pembelajaran pada Masa Pandemi Covid-19. SAP (Susunan Artikel Pendidikan), 5(1). https://doi.org/10.30998/sap.v5i1.6511.

Imania, K. A., \& Bariah, S. K. (2019). Rancangan Pengembangan Instrumen Penilaian Pembelajaran Berbasis Daring. Jurnal Petik, 5(1), 31-47. https://doi.org/10.31980/jpetik.v5i1.445.

Jaelani, A., Fauzi, H., Aisah, H., \& Zaqiyah, Q. Y. (2020). Penggunaan Media Online dalam Proses Kegiatan Belajar Mengajar PAI di Masa Pandemi Covid-19 (Studi Pustaka dan Observasi Online). Jurnal IKA PGSD (Ikatan Alumni PGSD) UNARS, 8(1), 12. https://doi.org/10.36841/pgsdunars.v8i1.579.

Kadi, T., \& Awwaliyah, R. (2017). Inovasi Pendidikan : Upaya Penyelesaian Problematika Pendidikan di Indonesia. Jurnal Islam Nusantara, 1(2). https://doi.org/10.33852/jurnalin.v1i2.32.

Komalasari, R. (2020). Manfaat Teknologi Informasi dan Komunikasi di Masa Pandemi Covid 19. Tematik, 7(1), 38-50. https://doi.org/10.38204/tematik.v7i1.369.

Koswara, I. (2018). Revitalisasi Pembangunan Pendidikan Melalui Pendekatan Komunikasi Pendidikan. Jurnal Agregasi: Aksi Reformasi Government Dalam Demokrasi, 6(1). https://doi.org/10.34010/agregasi.v6i1.849.

Langi, J. P. (2021). Pengaruh Pembelajaran Fisika secara Online Berbasis Zoom Meeting terhadap Hasil Belajar Mahasiswa. Jurnal Syntax Admiration, 2(1), 85-93. https://jurnalsyntaxadmiration.com/index.php/jurnal/article/view/145/255.

Layla, M. (2020). Analisis Kepuasan Penggunaan Aplikasi Zoom dalam Mengikuti Webinar Selama Pandemi Covid-19 Menggunakan Webqual 4.0 (Studi Kasus: Dosen Stain Sultan Abdurrahman Kepri). Tanjak: Journal of Education and Teaching, 1(2), 169-177. https://doi.org/10.35961/tanjak.v1i2.142.

Monica, J., \& Fitriawati, D. (2020). Efektivitas Penggunaan Aplikasi Zoom Sebagai Media Pembelajaran Online pada Mahasiswa Saat Pandemi Covid-19. Jurnal Communio: Jurnal Jurusan Ilmu Komunikasi, 9(2), 1630-1640. https://doi.org/10.35508/jikom.v9i2.2416.

Mu'ayyadah, M., \& Fatmawati, N. (2021). Pemanfaatan Teknologi sebagai Pembelajaran E-Learning Google Classroom pada Mata Pelajaran IPS. Jurnal of Social Science and Education, 2(1). https://doi.org/10.21154/asanka.v2i1.2364.

Nugraha, S. A., Sudiatmi, T., \& Suswandari, M. (2020). Studi Pengaruh Daring Learning terhadap Hasil Belajar Matematika Kelas IV. Jurnal Inovasi Penelitian, 1(3), 265-276. https://doi.org/10.47492/jip.v1i3.74.

Permatasari, Mia Indah. (2021). Implementasi Pembelajaran Kimia Berbasis Daring (Google Classroom Dan Zoom Cloud Meeting) di SMK Negeri 1 Tanjung Palas. Edutech : Jurnal Inovasi Pendidikan Berbantuan Teknologi, 1(2), 154-161. https://doi.org/10.51878/edutech.v1i2.480.

Pujowati, Y. (2021). Dinamika Kebijakan Pembelajaran Daring di Era Pandemi Covid-19. Jurnal Pamator, 14(2). https://doi.org/10.21107/pamator.v14i2.11574.

Rigianti, H. A. (2020). Kendala Pembelajaran Daring Guru Sekolah Dasar di Banjarnegara. Elementary School: Jurnal Pendidikan Dan Pembelajaran Ke-SD-An, 7(2). https://doi.org/10.31316/esjurnal.v7i2.768.

Salsabila, U. H., Sari, L. I., Lathif, K. H., Lestari, A. P., \& Ayuning, A. (2020). Peran Teknologi dalam Pembelajaran di Masa Pandemi Covid-19. Al-Mutharahah: Jurnal Penelitian Dan Kajian Sosial 
Keagamaan, 17(2), 188-198. https://doi.org/10.46781/al-mutharahah.v17i2.138.

Sartika, dewi. (2021). Dampak Pandemi Covid-19 pada Pembelajaran Daring di Pendidikan Madrasah Ibtidaiyah dan Sekolah Dasar di Kota Bima. Jurnal Kreatif, 19(2). https://doi.org/10.52266/kreatif.v19i1.683.

Satrianingrum, A. P., \& Prasetyo, I. (2020). Persepsi Guru Dampak Pandemi Covid-19 terhadap Pelaksanaan Pembelajaran Daring di PAUD. Jurnal Obsesi : Jurnal Pendidikan Anak Usia Dini, 5(1), 633. https://doi.org/10.31004/obsesi.v5i1.574.

Sobron, Bayu, Rani, \& S, M. (2019). Pengaruh Daring Learning terhadap Hasil Belajar IPA Siswa Sekolah Dasar. Prosiding Seminar Nasional Dan Enterpreneurship, 1-5. http://conference.upgris.ac.id/index.php/snse/article/view/204.

Suhendro, E. (2020). Strategi Pembelajaran Pendidikan Anak Usia Dini di Masa Pandemi Covid-19. Golden Age: Jurnal Ilmiah Tumbuh Kembang Anak Usia Dini, 5(3), 133-140. https://doi.org/10.14421/jga.2020.53-05.

Syarifudin, A. S. (2020). Impelementasi Pembelajaran Daring untuk Meningkatkan Mutu Pendidikan sebagai Dampak Diterapkannya Social Distancing. Jurnal Pendidikan Bahasa Dan Sastra Indonesia Metalingua, 5(1), 31-34. https://doi.org/10.21107/metalingua.v5i1.7072.

Tamin, haryeni. (2021). Persepsi Mahasiswa Sastra terhadap Pembelajaran Daring melalui Aplikasi Zoom. Jurnal Onoma: Pendidikan, Bahasa, Dan Sastra, 7(1), 132-143. https://doi.org/10.30605/onoma.v7i1.610.

Tanuwijaya, N. S., \& Tambunan, W. (2021). Alternatif Solusi Model Pembelajaran untuk Mengatasi Resiko Penurunan Capaian Belajar dalam Pembelajaran Tatap Muka Terbatas di Masa Pandemic Covid 19. Jurnal Manajemen Pendidikan, 10(2), 80-90. https://doi.org/10.33541/jmp.v10i2.3272.

Vegatama, M. R., \& Amiruddin. (2021). Pengaruh Platform Zoom terhadap Motivasi dan Hasil Belajar Mata Kuliah Kimia Migas Selama Pandemi Covid-19. Jurnal Educatin and Development, 9(3), 369-374. https://doi.org/10.37081/ed.v9i3.2822.

Wahyono, P., Husamah, H., \& Budi, A. S. (2020). Guru profesional di Masa Pandemi COVID-19: Review Implementasi, Tantangan, dan Solusi Pembelajaran Daring. Jurnal Pendidikan Profesi Guru, 1(1), 51-65. https://doi.org/10.22219/jppg.v1i1.12462.

Wilson, A. (2020). Penerapan Metode Pembelajaran Daring (Online) melalui Aplikasi Berbasis Android Saat Pandemi Global. SAP (Susunan Artikel Pendidikan), 5(1). https://doi.org/10.30998/sap.v5i1.6386.

Wiryanto, W. (2020). Proses Pembelajaran Matematika di Sekolah Dasar di Tengah Pandemi Covid-19. Jurnal Review Pendidikan Dasar, 6(2). https://doi.org/10.26740/jrpd.v6n2.p125-132.

Yunitasari, R., \& Hanifah, U. (2020). Pengaruh Pembelajaran Daring terhadap Minat Belajar Siswa pada Masa COVID-19. Edukatif: Jurnal Ilmu Pendidikan, 2(3), 232-243. https://doi.org/10.31004/edukatif.v2i3.142.

Zunanni, M. Y., \& Zahara, R. (2021). Implementasi Media Pembelajaran E-Learning Berbasis Imtera di Madrasah Ibtidaiyah. Sittah: Journal of Primary Education, 2(2). https://doi.org/https://doi.org/10.30762/sittah.v2i2.3397. 